\title{
3D Hydrogen-Bonded Network Built from Copper(II) Complexes of 1,3-Propanediamine
}

\author{
Alexandre O. Legendre, ${ }^{a}$ Fabiana C. Andrade, ${ }^{a}$ Sandra R. Ananias, ${ }^{a}$ Antonio E. Mauro, ${ }^{*, a}$ \\ Adelino V. G. Netto, ${ }^{a}$ Regina H. A. Santos, ${ }^{b}$ Janaina G. Ferreira ${ }^{b}$ and \\ Fabiane R. Martins ${ }^{b}$
}

\author{
${ }^{a}$ Instituto de Química de Araraquara, Universidade Estadual Paulista, CP 355, 14801-970 Araraquara-SP, Brazil \\ ${ }^{b}$ Instituto de Química de São Carlos, Universidade de São Paulo,CP 780, 13560-970 São Carlos-SP, Brazil
}

A reação entre $\mathrm{Cu}\left(\mathrm{NO}_{3}\right)_{2} .3 \mathrm{H}_{2} \mathrm{O}$ e 1,3-propanodiamina (pn), na presença de $\mathrm{NaN}_{3}$, conduziu à obtenção de um co-cristal 1:1 formado por $\left[\mathrm{Cu}\left(\mathrm{NO}_{3}\right)_{2}(\mathrm{pn})_{2}\right]$ e $\left[\mathrm{Cu}\left(\mathrm{N}_{3}\right)\left(\mathrm{NO}_{3}\right)(\mathrm{pn})_{2}\right](\mathbf{1}$ e 2), os quais foram caracterizados por análise elementar, espectroscopia no IV e difração de raios X por monocristal. Em ambos os compostos, os átomos de cobre(II) encontram-se em um ambiente octaédrico distorcido, com quatro ligações no plano basal formadas por quatro átomos de $\mathrm{N}$ de dois ligantes pn bidentados enquanto que as ligações axiais são formadas por dois átomos de $\mathrm{O}$ do ligante nitrato em 1 e por um átomo de $\mathrm{O}$ do ligante nitrato e um átomo de $\mathrm{N}$ do íon azida em 2. A estrutura cristalina consiste em dois complexos (1 e 2) cristalograficamente independentes, que se unem por uma série de ligações de hidrogênio do tipo $\mathrm{N}-\mathrm{H} \cdots \mathrm{O}$ e $\mathrm{N}-\mathrm{H} \cdots \mathrm{N}$ bem como interações por $\mathrm{C}-\mathrm{H} \cdots \mathrm{O}$. Novos synthons supramoleculares foram identificados pela ocorrência de dois modos geometricamente distintos de reconhecimento molecular envolvendo o íon $\mathrm{NO}_{3}^{-}$ e grupos amino dos ligantes pn.

The reaction of $\mathrm{Cu}\left(\mathrm{NO}_{3}\right)_{2} \cdot 3 \mathrm{H}_{2} \mathrm{O}$ with 1,3-propanediamine (pn), in the presence of $\mathrm{NaN}_{3}$, afforded a 1:1 co-crystal formed by $\left[\mathrm{Cu}\left(\mathrm{NO}_{3}\right)_{2}(\mathrm{pn})_{2}\right]$ and $\left[\mathrm{Cu}\left(\mathrm{N}_{3}\right)\left(\mathrm{NO}_{3}\right)(\mathrm{pn})_{2}\right](\mathbf{1}$ and 2), which were characterized by elemental analysis, IR spectroscopy and single crystal X-ray diffraction. In both compounds, the copper(II) centers are in a distorted octahedral environment, formed by four $\mathrm{N}$ atoms of two bidentate pn ligands in the basal plane, whereas the axial bonds are formed by two $\mathrm{O}$ atoms from the nitrate ligands in $\mathbf{1}$ and one $\mathrm{O}$ atom from the nitrate ligand and one $\mathrm{N}$ atom from the azide ion in $\mathbf{2}$. The asymmetric unit of the crystal consists of two crystallographically independent $\mathbf{1}$ and $\mathbf{2}$ complexes, which are held together in a 3D network by a series of $\mathrm{N}-\mathrm{H} \cdots \mathrm{O}$ and $\mathrm{N}-\mathrm{H} \cdots \mathrm{N}$ hydrogen bonds, as well $\mathrm{C}-\mathrm{H} \cdots \mathrm{O}$ interactions. New supramolecular synthons are identified by the occurrence of two geometrically distinct molecular recognition patterns involving the $\mathrm{NO}_{3}^{-}$ion and amino groups from pn ligands.

Keywords: copper(II) complexes, hydrogen bonds, supramolecular chemistry

\section{Introduction}

Much attention has been devoted to the investigation of transition metal-based supramolecular frameworks due to theoretical and challenging aspects in controlling the selfassembly processes, as well the potential uses of such materials in sensing, gas adsorption, magnetic devices, molecular electronics, porous and nanosized materials. ${ }^{1}$ Among the non-covalent interactions, which play a significant role in the molecular self-recognition of the components, within the crystal, the hydrogen bonding is

*e-mail: mauro@iq.unesp.br the most important interaction type, since it combines directionality with strength. ${ }^{2}$ Within this context, a large number of well-ordered architectures has been successfully built up by assembling discrete coordination compounds via hydrogen bonding motifs. ${ }^{3}$

In our recent works, ${ }^{4}$ we have obtained a series of multidimensional supramolecular systems based on the selfassembly of discrete $\left[\mathrm{Pd}(\mathrm{SCN})_{2}(3,5 \text {-dimethylpyrazole })_{2}\right]$, and $\left[\mathrm{M}(\mathrm{NCS})_{2}(\text { pyrazole })_{4}\right](\mathrm{M}=\mathrm{Co}, \mathrm{Ni})$ by means of intermolecular hydrogen bonds, type $\mathrm{N}-\mathrm{H} \cdots \mathrm{NCS}-\mathrm{Pd}$ and $\mathrm{N}-\mathrm{H} \cdots \mathrm{SCN}-\mathrm{M}$, respectively.

As part of our ongoing investigations on the coordination and supramolecular chemistry of metal pseudohalides complexes, ${ }^{4,5}$ we report herein the 
preparation and crystallographic studies on the co-crystal of $\left[\mathrm{Cu}\left(\mathrm{NO}_{3}\right)_{2}(\mathrm{pn})_{2}\right]\left[\mathrm{Cu}\left(\mathrm{N}_{3}\right)\left(\mathrm{NO}_{3}\right)(\mathrm{pn})_{2}\right]$.

\section{Experimental}

Synthesis of $\left[\mathrm{Cu}\left(\mathrm{NO}_{3}\right)_{2}(\mathrm{pn})_{2}\right]\left[\mathrm{Cu}\left(\mathrm{N}_{3}\right)\left(\mathrm{NO}_{3}\right)(\mathrm{pn})_{2}\right]$

To a solution of $\mathrm{Cu}\left(\mathrm{NO}_{3}\right)_{2} \cdot 3 \mathrm{H}_{2} \mathrm{O}(0.29 \mathrm{~g}, 1.20 \mathrm{mmol})$ in ethanol $\left(6.0 \mathrm{~cm}^{3}\right)$ was added 1,3 -propanediamine $(0.23$ $\mathrm{cm}^{3}, 2.76 \mathrm{mmol}$ ), followed by dropwise addition of an aqueous solution of $\mathrm{NaN}_{3}(0.16 \mathrm{~g}, 2.43 \mathrm{mmol})$. The obtained deep blue solution was stirred for $30 \mathrm{~min}$ and then kept at $4{ }^{\circ} \mathrm{C}$. After five days, blue crystals suitable for X-ray analysis were collected. Yield: $40 \%$. The results of $\mathrm{C}, \mathrm{H}, \mathrm{N}$ and $\mathrm{Cu}$ elemental analysis were in agreement with the formula. (Calc. for $\mathrm{C}_{12} \mathrm{H}_{40} \mathrm{~N}_{14} \mathrm{Cu}_{2} \mathrm{O}_{9}: \mathrm{C}, 22.12 ; \mathrm{H}$, $6.19 ; \mathrm{N}, 30.09 ; \mathrm{Cu}, 19.50 \%$, Found: C, 21.94; H, 6.49; N, 29.89; $\mathrm{Cu}, 19.45)$.

\section{Instrumentation}

The IR spectrum of the co-crystal was recorded as $\mathrm{KBr}$ pellets on a Nicolet IMPACT 400 spectrophotometer in the 4000-400 $\mathrm{cm}^{-1}$ wavelength range, at a resolution of $4 \mathrm{~cm}^{-1}$. C, $\mathrm{H}$, and $\mathrm{N}$ analysis were carried out with a CE Instruments EA1110 CHNS-O microanalyzer. The $\mathrm{Cu}$ content was determined following the literature procedure. ${ }^{6}$

\section{Crystal structure determination}

The data collections for a single crystal were carried out on an Enraf Nonius CAD4 diffractometer, using graphite monochromated $\operatorname{MoK}_{\alpha}(\lambda=0.71073 \AA)$ radiation. Twenty five reflections $(12.41<\theta<18.06)$ were used to determine the cell parameters, at room temperature. During the data collection 3 standard reflections were used with no significant decay. Intensities were corrected by absorption factors $\left[\mu\left(\mathrm{MoK}_{\alpha}\right)=1.643 \mathrm{~mm}^{-1}\right]$ using the PSISCAN method. ${ }^{7}$ Information concerning crystallographic data collection and refinement of the structure are given in Table 1. The structures were solved using the WinGX system ${ }^{8}$ by SIR $92,{ }^{9}$ and refined by full matrix least squares and difference Fourier synthesis using SHEL97. ${ }^{10}$ The final residual electronic density, is located around the copper atom. The hydrogen atoms were located in their ideal positions and not refined, with the thermal vibration parameters equal to 1.3 times the isotropic equivalent $\mathrm{U}$ of the attached atom. All non-hydrogen atoms were refined anisotropically. The structural analysis was performed by PLATON system. ${ }^{11}$

\section{Results and Discussion}

During our attempts to synthesize new $\mathrm{Cu}^{\mathrm{II}}$ azidocomplexes from the reaction between copper(II) nitrate and 1,3-propanediamine (pn) with two equivalents of $\mathrm{NaN}_{3}$, in an ethanol:water mixture, we have obtained

Table 1. Summary of data collection and refinement conditions

\begin{tabular}{|c|c|}
\hline & {$\left[\mathrm{Cu}\left(\mathrm{NO}_{3}\right)_{2}(\mathrm{pn})_{2}\right]\left[\mathrm{Cu}\left(\mathrm{NO}_{3}\right)\left(\mathrm{N}_{3}\right)(\mathrm{pn})_{2}\right]$} \\
\hline Empirical formula & $\mathrm{C}_{6} \mathrm{H}_{20} \mathrm{CuN}_{6} \mathrm{O}_{6}, \mathrm{C}_{6} \mathrm{H}_{20} \mathrm{CuN}_{8} \mathrm{O}_{3}$ \\
\hline Molecular weight & 651.68 \\
\hline Temperature/ K & 293 \\
\hline $\mathrm{K}_{\alpha} \mathrm{Mo}, \lambda / \AA$ & 0.71073 \\
\hline Crystal system & monoclinic \\
\hline Space Group & $\mathrm{P} 2 / \mathrm{n}$ \\
\hline $\mathrm{a} / \AA$ & $8.4624(8)$ \\
\hline $\mathrm{b} / \AA ̊$ & $10.7404(12)$ \\
\hline $\mathrm{c} / \AA ̊$ & $29.7142(34)$ \\
\hline$\beta /\left(^{\circ}\right)$ & $91.636(9)$ \\
\hline Volume/ $\AA^{3} ; \mathrm{Z}$ & $2699(2) ; 4$ \\
\hline $\mathrm{D}_{\mathrm{c}} /\left(\mathrm{Mg} \mathrm{m}^{-3}\right)$ & 1.603 \\
\hline$\mu / \mathrm{mm}^{-1}$ & 1.643 \\
\hline $\mathrm{F}(000)$ & 1360 \\
\hline Crystal size/ mm & $0.225 \times 0.350 \times 0.500$ \\
\hline$\theta$ range/ $\left({ }^{\circ}\right)$ & $2.5,25.2$ \\
\hline hkl(min:max.) & $10: 10 ; 0: 12 ; 0: 35$ \\
\hline Reflections collected; unique; $\mathrm{R}_{\text {int }}$ & $4891 ; 4796 ; 0.033$ \\
\hline Reflections observed $(\mathrm{I}>2 \sigma(\mathrm{I}))^{\mathrm{int}}$ & 3845 \\
\hline Refinement method & Full-matrix least-squares on F2 \\
\hline NPAR & 334 \\
\hline Speed scan $(\% / \min )$ (min:max.) & 2.74: 16.48 \\
\hline $\mathrm{R} ; \mathrm{wR}_{2} ; \mathrm{S}$ & $0.0321,0.0872,1.05$ \\
\hline Largest diff. peak and hole/ $\left(\mathrm{e} \AA^{-3}\right)$ & $0.522 ;-0.391$ \\
\hline
\end{tabular}


physical and analytical evidences of the formation of an unusual compound. Repeated elemental analysis results of the sample were consistent with a $\mathrm{C}_{12} \mathrm{H}_{40} \mathrm{~N}_{14} \mathrm{Cu}_{2} \mathrm{O}_{9}$ formulation. The $\mathrm{X}$-ray structural determination of this species was undertaken in order to get a better knowledge of its structure.

\section{X-ray crystallographic studies}

The co-crystallization of two different monomeric compounds in the asymmetric unit, $\left[\mathrm{Cu}\left(\mathrm{NO}_{3}\right)_{2}(\mathrm{pn})_{2}\right](\mathbf{1})$ and $\left[\mathrm{Cu}\left(\mathrm{N}_{3}\right)\left(\mathrm{NO}_{3}\right)(\mathrm{pn})_{2}\right](2)$, was definitely proved by the crystal and molecular structure X-ray analysis, corroborating the important structural features suggested by IR spectroscopy.

The molecular structures of the complexes $\left[\mathrm{Cu}\left(\mathrm{NO}_{3}\right)_{2}(\mathrm{pn})_{2}\right](\mathbf{1})$ and $\left[\mathrm{Cu}\left(\mathrm{N}_{3}\right)\left(\mathrm{NO}_{3}\right)(\mathrm{pn})_{2}\right](\mathbf{2})$, together with the crystallographic labeling scheme, are shown in Figures 1 and 2, respectively. Selected bond lengths and angles with their estimated standard deviations in parentheses are listed in Table 2 and 3, respectively.

In both compounds, the metal ion exhibits an elongated and distorted trans-octahedral geometry. The coordination polyhedron is defined by four nitrogen atoms at the equatorial plane from two chelating 1,3-propanediamine ligands: N1, N2, N3 and N4 at Cu1, for complex 1 and $\mathrm{N} 1 \mathrm{a}, \mathrm{N} 2 \mathrm{a}, \mathrm{N} 3 \mathrm{a}$ and $\mathrm{N} 4 \mathrm{a}$ at $\mathrm{Cu} 2$, for 2 , with average $\mathrm{Cu}-\mathrm{N}$ distances of 2.023(2) and 2.031(2) $\AA$, respectively. The sixmembered chelate rings formed by 1,3-propanediamine adopt the expected chair conformation. The atoms that constitute the basal plane do not deviate significantly from planarity, with the largest deviations being -0.133(3) $\AA$ for N1 and N3 and 0.137(2) $\mathrm{A}$ and 0.129(2) $\AA$ for N2 and N4 respectively. The $\mathrm{Cu} 1$ and $\mathrm{Cu} 2$ ions are displaced from the

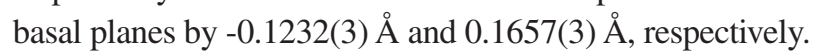
The axial positions of $\mathbf{1}$ are occupied by the $\mathrm{O} 5$ and $\mathrm{O} 3$ atoms of the monodentate nitrate $(\mathrm{Cu} 1-\mathrm{O} 3=2.927(3)$ and Cu1-O5 = 2.458(3) $\AA$ ) and, for the compound 2, they are

Table 2. Selected bond lengths (Å) for the co-crystal

\begin{tabular}{|c|c|c|c|c|c|c|c|c|}
\hline $\mathrm{Cu} 1$ & $\mathrm{O} 3$ & $2.927(3)$ & $\mathrm{Cu} 2$ & O9 & $2.990(4)$ & N1 & $\mathrm{C} 1$ & $1.464(4)$ \\
\hline $\mathrm{Cu} 1$ & O5 & $2.458(3)$ & $\mathrm{Cu} 2$ & N1A & $2.020(2)$ & $\mathrm{N} 2$ & $\mathrm{C} 3$ & $1.478(4)$ \\
\hline $\mathrm{Cu} 1$ & N1 & $2.019(2)$ & $\mathrm{Cu} 2$ & $\mathrm{~N} 2 \mathrm{~A}$ & $2.035(2)$ & N3 & $\mathrm{C} 4$ & $1.466(3)$ \\
\hline $\mathrm{Cu} 1$ & $\mathrm{~N} 2$ & $2.031(2)$ & $\mathrm{Cu} 2$ & N3A & $2.040(2)$ & N4 & C6 & $1.468(4)$ \\
\hline $\mathrm{Cu} 1$ & $\mathrm{~N} 3$ & $2.007(2)$ & $\mathrm{Cu} 2$ & $\mathrm{~N} 4 \mathrm{~A}$ & $2.028(2)$ & $\mathrm{N} 1 \mathrm{~A}$ & $\mathrm{C} 1 \mathrm{~A}$ & $1.467(4)$ \\
\hline $\mathrm{Cu} 1$ & $\mathrm{~N} 4$ & $2.036(2)$ & $\mathrm{Cu} 2$ & N5A & $2.333(2)$ & $\mathrm{N} 2 \mathrm{~A}$ & $\mathrm{C} 3 \mathrm{~A}$ & $1.477(3)$ \\
\hline $\mathrm{O} 1$ & N5 & $1.248(3)$ & O6 & N6 & $1.219(3)$ & $\mathrm{N} 3 \mathrm{~A}$ & $\mathrm{C} 4 \mathrm{~A}$ & $1.477(3)$ \\
\hline $\mathrm{O} 2$ & N5 & $1.239(3)$ & $\mathrm{O} 7$ & N7 & $1.252(3)$ & N4A & C6A & $1.479(3)$ \\
\hline $\mathrm{O} 3$ & N5 & $1.232(3)$ & O8 & N7 & $1.199(4)$ & N5A & N6A & $1.171(3)$ \\
\hline $\mathrm{O} 4$ & N6 & $1.224(4)$ & O9 & N7 & $1.196(4)$ & N6A & N7A & $1.169(3)$ \\
\hline O5 & N6 & $1.243(3)$ & & & & & & \\
\hline
\end{tabular}

Table 3. Selected angles $\left(^{\circ}\right)$ for the co-crystal

\begin{tabular}{|c|c|c|c|c|c|c|c|}
\hline $\mathrm{O} 3$ & $\mathrm{Cu} 1$ & O5 & $163.64(7)$ & N1A & $\mathrm{Cu} 2$ & $\mathrm{~N} 4 \mathrm{~A}$ & $169.44(8)$ \\
\hline $\mathrm{O} 3$ & $\mathrm{Cu} 1$ & $\mathrm{~N} 1$ & $81.44(7)$ & $\mathrm{N} 1 \mathrm{~A}$ & $\mathrm{Cu} 2$ & N5A & $95.59(8)$ \\
\hline $\mathrm{O} 3$ & $\mathrm{Cu} 1$ & N2 & $73.62(7)$ & $\mathrm{N} 2 \mathrm{~A}$ & $\mathrm{Cu} 2$ & N3A & $171.50(8)$ \\
\hline $\mathrm{O} 3$ & $\mathrm{Cu} 1$ & N3 & $84.72(8)$ & $\mathrm{N} 2 \mathrm{~A}$ & $\mathrm{Cu} 2$ & $\mathrm{~N} 4 \mathrm{~A}$ & $91.47(8)$ \\
\hline $\mathrm{O} 3$ & $\mathrm{Cu} 1$ & N4 & $107.01(8)$ & $\mathrm{N} 2 \mathrm{~A}$ & $\mathrm{Cu} 2$ & N5A & $91.88(8)$ \\
\hline O5 & $\mathrm{Cu} 1$ & N1 & $82.68(8)$ & N1A & $\mathrm{Cu} 2$ & $\mathrm{~N} 2 \mathrm{~A}$ & $86.46(8)$ \\
\hline O5 & $\mathrm{Cu} 1$ & N2 & $102.34(8)$ & N1A & $\mathrm{Cu} 2$ & N3A & $90.27(8)$ \\
\hline O5 & $\mathrm{Cu} 1$ & N3 & 111.37(8) & N4A & $\mathrm{Cu} 2$ & N5A & $94.83(8)$ \\
\hline O5 & $\mathrm{Cu} 1$ & N4 & $78.10(9)$ & $\mathrm{N} 3 \mathrm{~A}$ & $\mathrm{Cu} 2$ & $\mathrm{~N} 4 \mathrm{~A}$ & $90.32(9)$ \\
\hline N1 & $\mathrm{Cu} 1$ & $\mathrm{~N} 2$ & $89.42(8)$ & $\mathrm{N} 3 \mathrm{~A}$ & $\mathrm{Cu} 2$ & N5A & $96.26(8)$ \\
\hline N1 & $\mathrm{Cu} 1$ & N3 & $165.62(8)$ & $\mathrm{Cu} 2$ & N1A & $\mathrm{C} 1 \mathrm{~A}$ & $116.1(2)$ \\
\hline N1 & $\mathrm{Cu} 1$ & N4 & $94.38(9)$ & $\mathrm{Cu} 2$ & $\mathrm{~N} 2 \mathrm{~A}$ & $\mathrm{C} 3 \mathrm{~A}$ & $115.6(2)$ \\
\hline $\mathrm{N} 2$ & $\mathrm{Cu} 1$ & $\mathrm{~N} 3$ & $90.43(8)$ & $\mathrm{Cu} 2$ & N3A & $\mathrm{C} 4 \mathrm{~A}$ & $118.6(2)$ \\
\hline $\mathrm{N} 2$ & $\mathrm{Cu} 1$ & N4 & $176.20(9)$ & $\mathrm{Cu} 2$ & $\mathrm{~N} 4 \mathrm{~A}$ & C6A & $118.8(2)$ \\
\hline N3 & $\mathrm{Cu} 1$ & N4 & $85.91(9)$ & $\mathrm{Cu} 2$ & N5A & C6A & $112.2(2)$ \\
\hline $\mathrm{Cu} 1$ & $\mathrm{O} 3$ & N5 & $126.6(2)$ & $\mathrm{O} 1$ & N5 & $\mathrm{O} 2$ & $119.8(2)$ \\
\hline $\mathrm{Cu} 1$ & O5 & N6 & $115.3(2)$ & $\mathrm{O} 1$ & N5 & $\mathrm{O} 3$ & $119.5(2)$ \\
\hline $\mathrm{Cu} 1$ & N1 & $\mathrm{C} 1$ & 119.6(2) & $\mathrm{O} 2$ & N5 & $\mathrm{O} 3$ & $120.7(2)$ \\
\hline $\mathrm{Cu} 1$ & $\mathrm{~N} 2$ & $\mathrm{C} 3$ & $120.0(2)$ & $\mathrm{O} 4$ & N6 & O5 & $117.3(2)$ \\
\hline $\mathrm{Cu} 1$ & N3 & $\mathrm{C} 4$ & $115.7(2)$ & $\mathrm{O} 4$ & N6 & O6 & $123.6(3)$ \\
\hline $\mathrm{Cu} 1$ & N4 & C6 & 117.1(2) & O5 & N6 & O6 & 119.1(2) \\
\hline N5A & N6A & N7A & $178.5(2)$ & O8 & N7 & O9 & $125.9(3)$ \\
\hline O7 & N7 & O9 & $114.4(3)$ & $\mathrm{O} 7$ & N7 & O8 & 119.7(3) \\
\hline
\end{tabular}




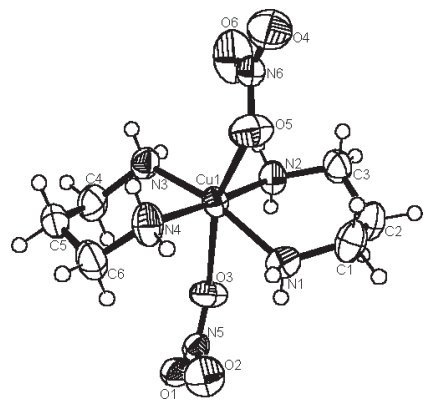

Figure 1. The ORTEP representation of the molecular structure with labeling scheme for $\left[\mathrm{Cu}\left(\mathrm{NO}_{3}\right)_{2}(\mathrm{pn})_{2}\right] \mathbf{1}$. Ellipsoids are shown at 50\% probability level.

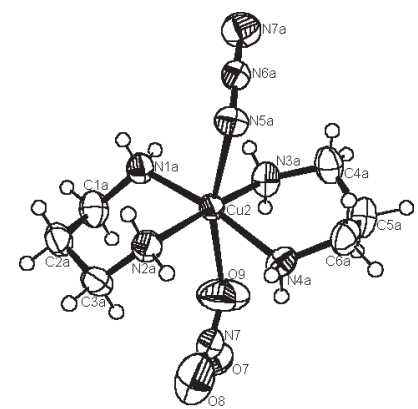

Figure 2. The ORTEP representation of the molecular structure with labeling scheme for $\left[\mathrm{Cu}\left(\mathrm{N}_{3}\right)\left(\mathrm{NO}_{3}\right)(\mathrm{pn})_{2}\right] 2$. Ellipsoids are shown at $50 \%$ probability level.

occupied by the N5a atom of the terminal azide and $\mathrm{O} 9$ of the other monodentate nitrate $(\mathrm{Cu} 2-\mathrm{N} 5 \mathrm{a}=2.333(2)$ and Cu2-O9 = 2.990(4) $\AA$ ).

The average $\mathrm{Cu}-\mathrm{N}(\mathrm{pn})$ distances of 2.023(2) (1) and 2.031(2) $\AA$ (2) are comparable with those found ${ }^{12}$ for $\left[\mathrm{Cu}\left(\mathrm{NO}_{3}\right)_{2}(\mathrm{dmpn})_{2}\right](\mathrm{dmpn}=\operatorname{bis}(1,3$-diamino-2,2dimethylpropane), $2.018 \AA$ and slightly longer than the values found ${ }^{13}$ for $\left[\mathrm{Cu}_{2}\left(\mathrm{~N}_{3}\right)_{4}(\mathrm{pn})_{2}\right], 2.000 \AA$. The $\mathrm{Cu}-\mathrm{N}($ azido) length of compound $\mathbf{2}$ of $2.333(2) \AA$ is significantly longer than those found ${ }^{14}$ for $\left[\mathrm{Cu}\left(\mathrm{N}_{3}\right)(\mathrm{NCO})(\mathrm{tmen})\right]_{2}\left(\mathrm{tmen}=N, N, N^{\prime}, N^{\prime}-\right.$ tetramethylethylenediamine), 2.000(1) $\AA$; $\left[\mathrm{Cu}\left(\mathrm{N}_{3}\right)(\mathrm{L})_{4}\right] \mathrm{ClO}_{4}$ $(\mathrm{L}=\beta \text {-collidine })^{15}, 2.141(6) \AA$; but comparable with the axial $\mathrm{Cu}-\mathrm{N}$ (azide) bond distances found ${ }^{16}$ for $\left[\mathrm{Cu}\left(\mathrm{N}_{3}\right)_{2}(\mathrm{diEten})\right]_{2}$ (diEten $=N, N$,-diethylethylenediamine), 2.333(3) $\AA$ and $\left[\mathrm{Cu}\left(\mathrm{N}_{3}\right)_{2}(\mathrm{tmen})\right]_{\mathrm{n}}, 2.346(3) \AA{ }^{14}$ The azide group is essentially linear $\left(\mathrm{N} 5 \mathrm{a}-\mathrm{N} 6 \mathrm{a}-\mathrm{N} 7 \mathrm{a}=178.5(2)^{\circ}\right)$.

In compound $\mathbf{1}$, the two axial $\mathrm{Cu}-\mathrm{O}$ bond distances are very different from each other: $\mathrm{Cu} 1-\mathrm{O} 3=2.927(3) \AA$ and $\mathrm{Cu} 1-\mathrm{O} 5=2.458(3) \AA$. The former apical $\mathrm{Cu}-\mathrm{O}$ bond distances for $\mathbf{1}$ as well that found for $\mathbf{2}(\mathrm{Cu} 2-\mathrm{O} 9=2.990(4)$ $\AA$ ) indicated the existence of very weak covalent interactions between one of the oxygen atom from the nitrate and $\mathrm{Cu}$ (II) ion. Despite the fact that these bond lengths are slightly longer than the sum of van der Waals radii of copper and oxygen $(2.90 \AA), \mathrm{Cu}-\mathrm{O}$ values within the range of 2.5 3.0 $\AA$ have been considered as long coordination distances for copper(II) complexes. ${ }^{17}$ For instance, Valdéz-Martinez et al. ${ }^{18}$ considered the coordination of the $\mathrm{NO}_{3}{ }^{-}$groups at the axial positions of $\left[\mathrm{Cu}\left(\mathrm{NO}_{3}\right)_{2}(\mathrm{MeTSC})_{2}\right]$, which exhibited $\mathrm{Cu}-\mathrm{O}$ bond length of 2.864(3) $\AA$. Copper-oxygen bond of 2.906(7) $\AA$ was also considered significant in the molecular structure of $\left[\mathrm{Cu}\left(\mathrm{NO}_{3}\right)_{2}(\text { py })_{2}\right]_{2} \cdot$ py $($ py $=$ pyridine $) .{ }^{19}$ Anyway, if one takes into account that $\mathrm{Cu} 1-\mathrm{O} 3$ and $\mathrm{Cu} 2-\mathrm{O} 9$ are nonbonding distances, the metal coordination polyhedron in $\mathbf{1}$ and $\mathbf{2}$ could alternatively be described as distorted square pyramidal.

The azide and nitrate groups participate in a series of hydrogen bonds which are responsible for the stabilization of the crystal structure. Table 4 lists the distances and angles of hydrogen bonds and $\mathrm{C}-\mathrm{H} \cdots \mathrm{O}$ interactions in the co-crystal.

Table 4. Hydrogen bonds distances and angles for the co-crystal $\left(\AA,^{\circ}\right)$

\begin{tabular}{|c|c|c|c|c|}
\hline $\mathrm{D}-\mathrm{H} \cdots \mathrm{A}$ & D-H/ ̊̊ & $\mathrm{H} \cdots \mathrm{A} / \AA ̊$ & $\mathrm{D} \cdots \mathrm{A} / \AA$ & $\mathrm{D}-\mathrm{H} \cdot \cdots \mathrm{A} /\left(^{\circ}\right)$ \\
\hline $\mathrm{N} 1-\mathrm{H} 1 \mathrm{~N} 1 \cdots \mathrm{N} 7 \mathrm{~A}$ & 0.90 & 2.30 & $3.17(4)$ & 166 \\
\hline $\mathrm{N} 1-\mathrm{H} 2 \mathrm{~N} 1 \cdots \mathrm{N} 7 \mathrm{~A}^{\mathrm{a}}$ & 0.90 & 2.61 & $3.33(4)$ & 138 \\
\hline $\mathrm{N} 2-\mathrm{H} 2 \mathrm{~N} 2 \cdots \mathrm{O}^{\mathrm{b}}$ & 0.90 & 2.14 & $3.00(3)$ & 161 \\
\hline $\mathrm{N} 4 \mathrm{~A}-\mathrm{H} 1 \mathrm{~A} 4 \cdots \mathrm{O}^{\mathrm{c}}$ & 0.90 & 2.22 & $3.07(4)$ & 159 \\
\hline $\mathrm{N} 4 \mathrm{~A}-\mathrm{H} 2 \mathrm{~A} 4 \cdots \mathrm{O}^{\mathrm{d}}$ & 0.90 & 2.28 & $3.02(4)$ & 139 \\
\hline $\mathrm{N} 2 \mathrm{~A}-\mathrm{H} 1 \mathrm{~A} 2 \cdots \mathrm{O}^{\mathrm{c}}$ & 0.90 & 2.58 & $3.32(4)$ & 140 \\
\hline $\mathrm{N} 2 \mathrm{~A}-\mathrm{H} 2 \mathrm{~A} 2 \cdots \mathrm{O}^{\mathrm{a}}$ & 0.90 & 2.24 & $3.09(3)$ & 159 \\
\hline $\mathrm{N} 2-\mathrm{H} 1 \mathrm{~N} 3 \cdots \mathrm{O} 7$ & 0.90 & 2.14 & $3.02(4)$ & 166 \\
\hline $\mathrm{N} 3-\mathrm{H} 2 \mathrm{~N} 3 \cdots \mathrm{O}^{\mathrm{b}}$ & 0.90 & 2.57 & $3.39(3)$ & 152 \\
\hline $\mathrm{N} 3-\mathrm{H} 2 \mathrm{~N} 3 \cdots \mathrm{O}^{\mathrm{b}}$ & 0.90 & 2.36 & $3.19(4)$ & 154 \\
\hline $\mathrm{N} 3 \mathrm{~A}-\mathrm{H} 1 \mathrm{~A} 3 \cdots \mathrm{O}^{\mathrm{d}}$ & 0.90 & 2.25 & $2.92(4)$ & 130 \\
\hline $\mathrm{N} 1 \mathrm{~A}-\mathrm{H} 11 \mathrm{~A} \cdots \mathrm{O}^{\mathrm{a}}$ & 0.90 & 2.44 & $3.33(4)$ & 169 \\
\hline $\mathrm{N} 3 \mathrm{~A}-\mathrm{H} 2 \mathrm{~A} 3 \cdots \mathrm{O} 5$ & 0.90 & 2.47 & $3.33(4)$ & 160 \\
\hline $\mathrm{N} 4-\mathrm{H} 1 \mathrm{~N} 4 \cdots \mathrm{N} 7 \mathrm{~A}$ & 0.90 & 2.07 & $2.97(4)$ & 178 \\
\hline $\mathrm{N} 4-\mathrm{H} 2 \mathrm{~N} 4 \cdots \mathrm{O} 8$ & 0.90 & 2.57 & $3.46(5)$ & 171 \\
\hline $\mathrm{N} 1 \mathrm{~A}-\mathrm{H} 21 \mathrm{~A} \cdots \mathrm{O} 5$ & 0.90 & 2.27 & $3.16(4)$ & 168 \\
\hline $\mathrm{C} 4 \mathrm{~A}-\mathrm{H} 2 \mathrm{~B} 4 \cdots \mathrm{O} 8$ & 0.97 & 2.53 & $3.28(5)$ & 134 \\
\hline $\mathrm{C} 1-\mathrm{H} 1 \mathrm{C} 1 \cdots \mathrm{O}^{\mathrm{a}}$ & 0.97 & 2.51 & $3.12(4)$ & 120 \\
\hline
\end{tabular}

Symmetry code: $\mathrm{a}=-1-\mathrm{x},-\mathrm{y}, 1-\mathrm{z} ; \mathrm{b}=1-\mathrm{x},-1-\mathrm{y}, 1-\mathrm{z} ; \mathrm{c}=\mathrm{x}, 1+\mathrm{y}, \mathrm{z} ; \mathrm{d}=3 / 2-\mathrm{x}, 1 / 2+\mathrm{y},-\mathrm{z}$; 
As can be observed in Figure 3, each molecule of $\left[\mathrm{Cu}\left(\mathrm{NO}_{3}\right)_{2}(\mathrm{pn})_{2}\right](\mathbf{1})$ and $\left[\mathrm{Cu}\left(\mathrm{N}_{3}\right)\left(\mathrm{NO}_{3}\right)(\mathrm{pn})_{2}\right](2)$ of the asymmetric unit are assembled by $\mathrm{N}-\mathrm{H} \cdots \mathrm{O}$ and $\mathrm{N}-\mathrm{H} \cdots \mathrm{N}$ intermolecular hydrogen bonds. One oxygen atom from the $\mathrm{NO}_{3}^{-}$group of $\mathbf{1}$ takes part in two hydrogen bonds with two amino groups from distinct pn ligands of $\mathbf{2}$, leading to the formation of $R_{2}^{1}(6)$ rings (N1a $\cdots \mathrm{O} 5=3.16(4) \AA, \mathrm{N} 3 \mathrm{a} \cdots \mathrm{O} 5=$ 3.33(4) A). Similarly, the N1 and N4 atoms from 1,3propanediamine ligands in $\mathbf{1}$ form two hydrogen bonds with N7a atom from the $\mathrm{N}_{3}^{-}$group of $\mathbf{2}$, affording the hydrogenbond pattern $R_{2}^{1}$ (6).

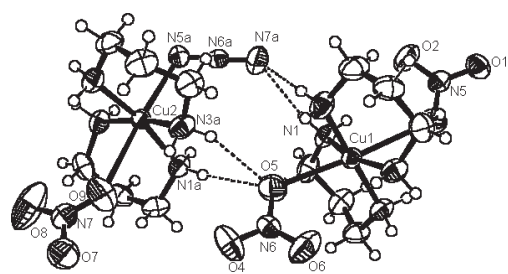

Figure 3. Packing view of the asymmetric unit of the co-crystal $\left[\mathrm{Cu}\left(\mathrm{NO}_{3}\right)_{2}(\mathrm{pn})_{2}\right]\left[\mathrm{Cu}\left(\mathrm{NO}_{3}\right)\left(\mathrm{N}_{3}\right)(\mathrm{pn})_{2}\right]$.

The association of $\left[\mathrm{Cu}\left(\mathrm{NO}_{3}\right)_{2}(\mathrm{pn})_{2}\right]$ molecules via $\mathrm{N}-\mathrm{H} \cdots \mathrm{O}$ intermolecular hydrogen bonds (Figure 4) is also noticed. The hydrogen-bonding motif $R_{2}^{2}(8)$ is formed by the $\mathrm{O}^{*}$ and $\mathrm{O}^{*}$ atoms from the $\mathrm{NO}_{3}{ }^{-}$group of a monomer involved in two hydrogen bonds with $\mathrm{H} 2(\mathrm{~N} 2)$ and $\mathrm{H} 2(\mathrm{~N} 3)$, respectively, from pn ligands of the adjacent monomer and vice-versa $(\mathrm{N} 2 \cdots \mathrm{O} 1 *=3.00(3) \AA, \mathrm{N} 3 \cdots \mathrm{O} 3 *=3.19(4))$. These molecules are also connected by bifurcated hydrogen bonds between $\mathrm{O}^{*}$ and $\mathrm{O}^{*}$ and $\mathrm{H} 2(\mathrm{~N} 3)$ atoms.

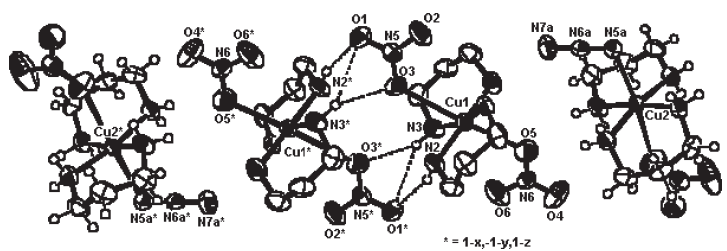

Figure 4. ORTEP representation of two molecules of $\mathbf{1}$ and $\mathbf{2}$ showing $\mathrm{N}-\mathrm{H} \cdots \mathrm{O}$ intermolecular hydrogen bonds.

Hydrogen bonding motifs of the type $R_{2}^{2}(8)$ are also present in the assembly of $\left[\mathrm{Cu}\left(\mathrm{NO}_{3}\right)_{2}(\mathrm{pn})_{2}\right](\mathbf{1})$ and $\left[\mathrm{Cu}\left(\mathrm{N}_{3}\right)\left(\mathrm{NO}_{3}\right)(\mathrm{pn})_{2}\right]$ (2) molecules (Figure 5). The $\mathrm{O} 1$ and $\mathrm{O} 2$ atoms from a nitrate group of $\mathbf{1}$ take part in two intermolecular hydrogen bonds between $\mathrm{H} 2\left(\mathrm{~N} 2 \mathrm{a}^{*}\right)$ and $\mathrm{H} 1(\mathrm{~N} 1 * \mathrm{a})$ atoms, respectively, of two pn ligands of a neighboring molecule of $\mathbf{2}\left(\mathrm{N} 2 \mathrm{a}^{*} \ldots \mathrm{O} 1=3.09(3) \AA, \mathrm{N} 1 \mathrm{a}^{*} \ldots \mathrm{O} 2\right.$ $=3.33(4)$ ). In addition, monomers of $\mathbf{1}$ are connected by intermolecular contacts of the type $\mathrm{C} 1 *-\mathrm{H} 1 \cdots \mathrm{O} 2(\mathrm{C} 1 * \ldots \mathrm{O} 2$ $=3.12(4) \AA, \mathrm{C} 1^{*}-\mathrm{H} \cdots \mathrm{O} 2=120^{\circ}$ ).

These intermolecular forces are responsible for the selfassembly of the 1D chains of $\mathbf{1}$ and $\mathbf{2}$ into a three-dimensional supramolecular network, which is illustrated in Figure 6.

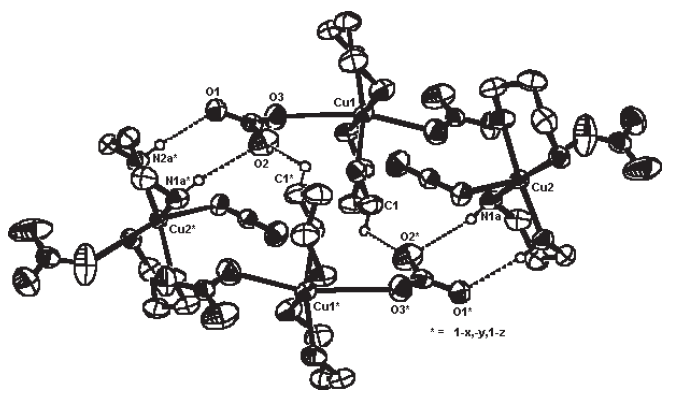

Figure 5. ORTEP representation of four molecules of $\mathbf{1}$ and $\mathbf{2}$ showing $\mathrm{N}-\mathrm{H} \cdots \mathrm{O}$ intermolecular hydrogen bonds and $\mathrm{C}-\mathrm{H} \cdots \mathrm{O}$ interactions.

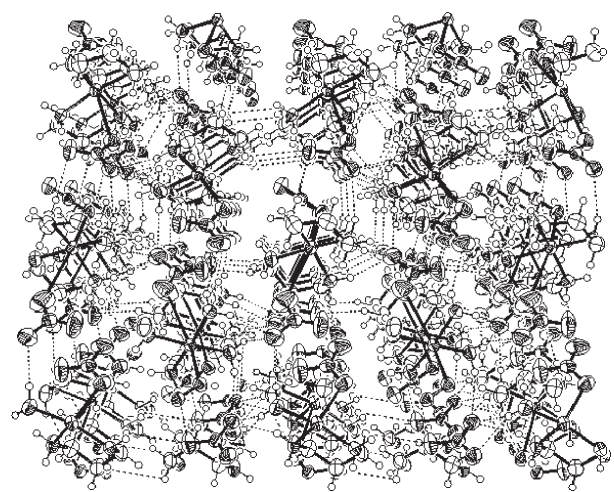

Figure 6. Perspective view of the 3D supramolecular network in the cocrystal.

From the crystal engineering point of view, the crystal structure described in this paper clearly demonstrated two geometrically distinct supramolecular synthons (synthons I and II) which are generated from the molecular recognition between the hydrogen bond donating $\mathrm{NH}_{2}$ groups from chelating 1,3-propanediamine ligands and HB-accepting site of nitrate group (Scheme 1).<smiles>ON1ON2CCCNC23NCCCN13</smiles><smiles>OCCNC12NCCCN1CN2ON(O)O</smiles>

Scheme 1.

IR spectroscopy

The IR spectrum of the co-crystal $\left[\mathrm{Cu}\left(\mathrm{NO}_{3}\right)_{2}(\mathrm{pn})_{2}\right]$ and $\left[\mathrm{Cu}\left(\mathrm{N}_{3}\right)\left(\mathrm{NO}_{3}\right)(\mathrm{pn})_{2}\right](\mathbf{1}$ and $\mathbf{2})$ displayed a number of absorption bands attributed to vibrational modes of 1,3propanediamine at $3262 \mathrm{~cm}^{-1}\left(\mathrm{v}_{\mathrm{as}} \mathrm{NH}_{2}\right), 3157 \mathrm{~cm}^{-1}\left(\mathrm{v}_{\mathrm{s}} \mathrm{NH}_{2}\right)$ and $1580 \mathrm{~cm}^{-1}\left(\delta \mathrm{NH}_{2}\right)$. However, the main interest in IR spectrum of the compounds 1-2 lies in the bands associated with the vibrational modes of $\mathrm{N}_{3}$ and $\mathrm{NO}_{3}{ }^{-}$groups as they can be very useful for the diagnosis of their coordination mode. The first feature of the IR spectrum of the co-crystal was the occurrence of a strong band at $2032 \mathrm{~cm}^{-1}$ assigned to $v_{\text {ass }} \mathrm{N}_{3}$ and indicative of azide group terminally coordinated to the copper atom. ${ }^{17}$ The presence of the 
nitrate group is evidenced by the appearance of a strong and narrow band at $1383 \mathrm{~cm}^{-1}$ (vONO).

\section{Conclusions}

In this work, we describe the X-ray structural characterization of an unusual 1:1 co-crystal of $\left[\mathrm{Cu}\left(\mathrm{NO}_{3}\right)_{2}(\mathrm{pn})_{2}\right](\mathbf{1})$ and $\left[\mathrm{Cu}\left(\mathrm{N}_{3}\right)\left(\mathrm{NO}_{3}\right)(\mathrm{pn})_{2}\right](\mathbf{2})$. The crystal structure consists of 1D hydrogen-bonded chains of $\mathbf{1}$ and $\mathbf{2}$ which are interconnected by $\mathrm{N}-\mathrm{H} \cdots \mathrm{O}$ and $\mathrm{N}-\mathrm{H} \cdots \mathrm{N}$ hydrogen bonds and $\mathrm{C}-\mathrm{H} \cdots \mathrm{O}$ contacts to yield a three-dimensional supramolecular array.

In the context of supramolecular chemistry and crystal engineering of the transition metal-based species, it is of vital importance to identify and understand the role played by new inorganic supramolecular synthons in the molecular aggregation within the crystal since they can be important tools in the rational construction of well-ordered structures. A systematic work on the creation of novel supramolecular architectures is currently underway in our laboratory.

\section{Acknowledgments}

The authors wish to acknowledge CNPq, FAPESP and CAPES for financial support.

\section{Supplementary Information}

Additional materials, consisting of atomic coordinates and equivalent isotropic displacement parameters for nonhydrogen atoms, $\mathrm{H}$-atom coordinates and isotropic displacement parameters, bond lengths and interbond angles have been deposited with the Cambridge Crystallographic Data Centre, CCDC, No. CCDC 276281. Copies of available material can be obtained on application to CCDC, 12, Union Road, Cambridge CB2 IEZ, UK (fax 44-1223336033 or e-mail:deposit@ccdc.cam.ac.uk).

\section{References}

1. Chae, H. K.; Siberio-Pérez, D. Y.; Kim, J.; Go, Y.; Eddaoudi, M.; Matzger, A. J.; O'Keeffe, M.; Yaghi, O. M.; Nature 2004, 427, 523; Takamizawa, S.; Nakata, E.; Saito, T.; Inorg. Chem. Commun. 2004, 7, 125; Li, M.; Cai, P.; Duan, C.; Lu, F.; Xie, J.; Meng, Q.; Inorg. Chem. 2004, 43, 5174; Balzani, V.; Ceroni, P.; Ferrer, B.; Pure Appl. Chem. 2004, 76, 1887; Barnett, S. A.; Champness, N. R.; Coord. Chem. Rev. 2003, 246, 145; Dinolfo, P. H.; Hupp, J. T.; Chem. Mater. 2001, 13, 3113; Kahn, O.; Acc. Chem. Res. 2000, 33, 647.

2. Braga, D.; Maini, L.; Polito, M.; Tagliavini, E.; Grepioni, F.; Coord. Chem. Rev. 2003, 246, 53; Tadokoro, M.; Nakasuji, K.; Coord. Chem. Rev. 2000, 198, 205.
3. Moulton, B.; Zaworotko, M. J.; Chem. Rev. 2001, 101, 1629.

4. Takahashi, P. M.; Melo, L. P.; Frem, R. C. G.; Netto, A. V. G.; Mauro, A. E., Santos, R. H. A.; Ferreira, J. G.; J. Mol. Struct. 2006, 783, 161; Netto, A. V. G.; Frem, R. C. G.; Mauro, A. E.; Almeida, E. T.; Santana, A. M.; Souza Jr., J.; Santos, R. H. A.; Inorg. Chim. Acta 2003, 350, 252.

5. Netto, A. V. G.; Frem, R. C. G.; Mauro, A. E.; Polyhedron 2005, 24, 1086; Silva, P. B.; Frem, R. C. G.; Netto, A. V. G.; Mauro, A. E.; Ferreira, J. G.; Santos, R. H. A.; Inorg. Chem. Commun. 2006, 9, 235; Almeida, E. T.; Santana, A. M.; Netto, A. V. G.; Mauro, A. E.; Santos, M. P.; Santos, R. H. A.; Z. Kristallogr. New Cryst. Struct. 2002, 217, 366; Sargentelli, V.; Benedetti, A. V.; Mauro, A. E.; J. Braz. Chem. Soc. 1997, 8, 271.

6. Oliveira, C. N.; Ionashiro, M.; Graner, C. A. F.; Eclet. Quim. $1985,10,7$.

7. North, A. C. T.; Phillips, D. C.; Mathews, F. S.; Acta Crystallogr. 1968, A24, 351.

8. Farrugia, L. J.; J. Appl. Crystallogr. 1999, 32, 837.

9. Altomare, G.; Cascarano, C.; Giacovazzo, C.; Guagliardi, A.; J. Appl. Crystallogr. 1993, 26, 343.

10. Sheldrick, G. M.; SHELX97, Programs for Crystal Structure Analysis (Release 97-2), University of Göttingen: Germany,1997; Sheldrick, G. M.; Institüt für Anorganische Chemie der Universität, Tammanstrasse 4, D-3400 Göttingen, Germany, 1998.

11. Speck, A. L.; PLATON, A Multipurpose Crystallographic Tool, Utrecht University: Utrecht, The Netherlands, 1998.

12. Stergiou, A. C.; Papastephanou, S.; Tsiamis, C.; Polyhedron 1994, 13, 2285.

13. Luo, J.; Zhou, X. G.; Gao, S.; Weng, L. H.; Shao, Z. H.; Zhang, C. M.; Li, Y. R.; Zhang, J.; Cai, R. F.; Polyhedron 2004, 23, 1243.

14. Mauro, A. E.; Haddad, P. S.; Zorel Júnior, H. E.; Santos, R. H. A.; Ananias, S. R.; Martins, F. R.; Tarrasqui, L. H. R.; Transition Met. Chem. 2004, 29, 893.

15. Mautner, F. A.; Goher, M. A. S.; Polyhedron 1996, 15, 1133.

16. Casagrande Jr., O. L.; Klein, S. I.; Mauro, A. E.; Tomita, K.; Transition Met. Chem. 1989, 14, 45.

17. Hathaway, B. J.In Comprehensive Coordination Chemistry; Wilkinson, G., ed., Pergamon: Oxford, 1987, ch. 53.

18. Valdés-Martínez; Toscano, R. A.; Ramirez-Ortíz, J.; Polyhedron 1995, 14, 579.

19. Cameron, A. F.; Forrest, K. P.; Taylor, D. W.; Nuttall, R. H.; J. Chem. Soc. A 1971, 2492.

20. Nakamoto, K.; Infrared and Raman Spectra of Inorganic and Coordination Compounds, $4^{\text {th }}$ ed., John Wiley \& Sons: New York, 1986.

Received: June 7, 2006

Published on the web: November 10, 2006

FAPESP helped in meeting the publication costs of this article. 